\title{
COMPARATIVE STUDIES ON ENDOGENOUS CREATININE AND UREA CLEARANCES IN PARAPLEGICS AND TETRAPLEGICS
}

\author{
By J. R. Doggart, Ph.D., L. Guttmann, C.B.E., M.D., F.R.C.P., F.R.C.S., \\ and J. R. SILVER, M.R.C.P.Ed. \\ National Spinal Injuries Centre, Stoke Mandeville Hospital, Aylesbury, Bucks.
}

THE most serious consequence of injuries to the spinal cord is progressive deterioration of renal function as a result of the ascending infection of the paralysed bladder. Although the advances made in the management of paraplegics since World War II have eliminated the early high mortality from renal infection experienced in World War I, there is still a high morbidity and mortality in the late stages from renal failure.

The most recent statistical review on patients suffering from spinal cord lesions has been published by Guttmann (I964). There were I963 traumatic paraplegics and tetraplegics among 3000 patients treated between 1944 and 1963 at the National Spinal Injuries Centre. The mortality among the I963 traumatic cases was 33I (I6.9 per cent.), the corrected figure, i.e. excluding those who died from causes unrelated to the spinal cord injury, being i I.5 per cent. Renal failure was still the main cause of death; this confirmed his earlier findings (Guttmann, I953). In an analysis of 9I autopsies from this series, Tribe (1963) found that 53 of the deaths could be attributed to chronic pyelonephritis, amyloidosis and hypertension. Similar observations have been made in recent years by other workers in this field (Reingold, I953; Damanski \& Gibbon, I956; Dietrick \& Russi, I958; Nyquist, I960; Breithaupt, Jousse \& Wynn-Jones, I96I; Comarr, Kawaichi \& Bors, I96I).

Since the prognosis of paraplegic patients is largely determined by the functional integrity of their kidneys, it is desirable to have reliable tests of renal function which can be conveniently performed at regular intervals. Rogers and Bors (1950), Comarr (1954), Morales, Sullivan and Hotchkiss (1956) and Magee (1957, I958) have studied the renal function of paraplegics using various tests of glomerular and tubular function, including the Inulin and P.A.H. clearances. However, Inulin and P.A.H. clearances require infusions and frequent blood samples. Moreover, these investigations were carried out almost exclusively on patients suffering from chronic infection of the urinary tract in later stages following spinal cord injuries. On the other hand, although the blood urea and the urea clearance tests are more convenient to perform, their validity as tests of renal function has been criticised (De Wardener, I96I; Wrong, I962; Berlyne et al., I964).

In the present paper an account is given of a comparative study on the endogenous creatinine and urea clearances as well as serum creatinine and bloodurea as tests of renal function in paraplegic and tetraplegic patients. The patients were studied at various stages following spinal cord injuries. Special attention was paid to the study of patients in the immediate and very early stages after spinal cord transection.

Clinical Material. Twenty-eight patients were examined: 26 resulted from trauma of the spine. One patient had a haemangioma and another had multiple sclerosis. They were all men aged between 15 and 59. With the exception of three, 
all had complete lesions at various levels ranging from $\mathrm{C}_{5}$ to $\mathrm{S}_{2}$. They can be conveniently divided into two groups. The first group, called 'acute' cases, consists of Io subjects who were first examined within three days of sustaining a complete lesion of the spinal cord between the fifth cervical and the third lumbar segments. They were studied on at least four successive days and six were followed up from 13 to 32 days after injury.

The second group, called 'chronic' cases, consists of I 8 subjects with renal impairment. Three of these had developed their renal impairment within 14 months of injury. The remaining I5 subjects were studied $5 \frac{1}{2}$ to 20 years after they had developed their cord lesion. All patients in this group were suffering from chronic pyelonephritis with recurrent pyrexial attacks, persistent positive urine cultures and proteinuria. Some had calculosis, hypertension, vesico-ureteric reflux, or hydro- or pyonephrosis as shown by pyelography or at operation. In I I of these subjects a diagnosis of amyloidosis was established either by rectal biopsy or postmortem. In one of these (T. H.), a man aged 4I with a TI2 lesion, amyloidosis was diagnosed by rectal biopsy as early as 19 months after injury.

Analytical Methods. A total of I2 I creatinine clearance tests and 99 urea clearance tests have been performed. Creatinine clearances were carried out over 24 -hour periods in all cases. Urea clearances in the chronic cases and in four of the acute cases were carried out over two one-hour periods; in the remainder of the acute cases 24 -hour collections were used. In all cases except C. L., who passed urine by expression of the bladder, urine was obtained by catheter.

Urine creatinine was determined by the method of Bonsnes and Taussky (1945), which is based on the Jaffe reaction. Immediate analysis of the urine was not crucial as it was found that after standing for four days at room temperature, the changes in creatinine concentration of Io random specimens ranged from -2 to $+4 \mathrm{mg}$./100 ml., with an average of $+0.8 \mathrm{ml}$. $/ \mathrm{r} 00 \mathrm{ml}$. Urine urea was determined on the autoanalyser by a diacetyl method in the majority of cases; in a limited number of the acute cases it was measured by the hypobromite method. It is recognised that the latter method does not give as accurate results as the diacetyl method. A much more serious source of error in determining the urinary urea arises from the presence of urea-splitting organisms (e.g. Proteus), in the bladder, leading to breakdown of urea before and after voiding, with the result that it is impossible to be certain that an accurate estimate of the urea output is being obtained.

One sample of blood was taken during the period of urine collection and analysed for creatinine by the method of King and Wooton (1956), in which the effect of interfering chromogens is minimised by adsorption on Lloyd's reagent prior to the carrying out of the Jaffe reaction. The drawback of this method, in the non-specificity of the colour reaction, is recognised, but it is the best available for routine use. Blood urea was determined on the autoanalyser by the diacetyl method.

In four of the chronic patients with amyloidosis the ability to concentrate urine was investigated by depriving them of food and drink from 7 p.m. the previous evening until Io a.m. on the day of investigation. Separate hourly specimens of urine were taken from 7 a.m. until Io a.m. The osmolality of the urine was determined on an advanced osmometer.

The results have not been corrected for surface area; this is never measured directly but is derived from a formula incorporating the height and weight of the patient. The clinical state of the acute cases and the presence of traction apparatus in tetraplegic patients precluded their being weighed. Moreover, the retention of fluid in the early stage, in particular following spinal cord injuries at higher level, could have led to considerable fluctuations in weight. In the chronic cases the pathological changes in the kidneys were generally of such a degree that such correction seemed superfluous. 


\section{RESULTS}

(a) Acute Cases. Five of the ten acute cases were examined as soon as within 24 hours of injury, three within 48 hours of injury, and two within 72 hours of injury. Follow-up studies were carried out for a minimum of four days. The results of the parallel clearance studies on these IO acute cases are shown in Table I. They are arranged in order according to the level of the cord injury.

Figures are given for the serum creatinine level in $\mathrm{mg}$./ $100 \mathrm{ml}$., the creatinine clearance in $\mathrm{ml} . / \mathrm{min}$. (performed on 24-hour specimens of urine), the blood urea concentration in $\mathrm{mg}$./ $/ \mathrm{poO} \mathrm{ml}$. and the urea clearance as percentage of average normal.

In six patients (T. J., G. McH., L. S., N. L., D. A. and W. G.) together with the final clearance on D. W. the urea clearance tests were performed over 24 hours. In the remaining four patients (S. I., D. K., D. W. and R. T.) the urea clearance tests were performed over two consecutive one-hour periods; the results for these periods are presented in brackets preceded by the average values. In most clearances the urine flow was less than $2 \mathrm{ml} / \mathrm{min}$. and every subject had at least one clearance study when the urine flow was less than I ml./min. The Van Slyke formula was used to correct for this.

On three occasions (S. I. third day, D. K. fourth day and D. W. third day) it was impossible to collect two one-hour specimens of urine, because the catheters were blocked; accordingly, no figures are given for those days. On five other occasions (S. I. fourth day, D. K. first day, D. W. second day and R. T. fourth and sixth days) there was such a divergence between the urea clearance values obtained during the two separate one-hour periods that the tests were regarded as technically unsatisfactory and no average figure for urea clearance has been given; the reasons for these discrepancies were gross differences in the volumes and urea concentrations in the two specimens. Taking the lower limit of normal for urea clearance as 70 per cent. average normal, there were seven low-urea clearance values, but there were 12 other instances in which no value has been recorded for various reasons. Bearing in mind the fact that the Van Slyke correction formula had to be used, the poor correlation of the one-hour tests and the inherent error of a 24-hour urea clearance test, it was not thought profitable to pay too much attention to the urea clearance.

In only two cases (T. J. and D. K.) was a serum creatinine level found above the normal maximum (I.2 mg./100 ml.). In each case this was on the first day after injury. Taking the lower limit of normal for creatinine clearance in men as 78 ml./min. (Tobias, McLaughlin \& Hopper, 1962), seven of the creatinine clearance figures in Table I were below normal. It may be noted that the abnormally low creatinine clearance figures coincided only in two cases (T. J. and D. K.) with increased serum creatinine levels, while in the other cases (G. McH., L. S. and D. A.) the serum creatinine was within normal limits.

Only two patients (R. T. and D. A.) did not show on at least one occasion a blood urea level above a widely accepted normal limit of $40 \mathrm{mg}$./ $100 \mathrm{ml}$. (Varley, 1954). One patient (D. K.), who had a fractured pelvis and large haematomata in the groins, showed a figure of $83 \mathrm{mg}$./ $100 \mathrm{ml}$. on the first day after injury. The final column gives some clinical details, from which it can be seen that the two patients had normal blood urea concentrations throughout, had minor abrasions only in addition to their cord injury, whereas four of the remaining patients with raised blood 


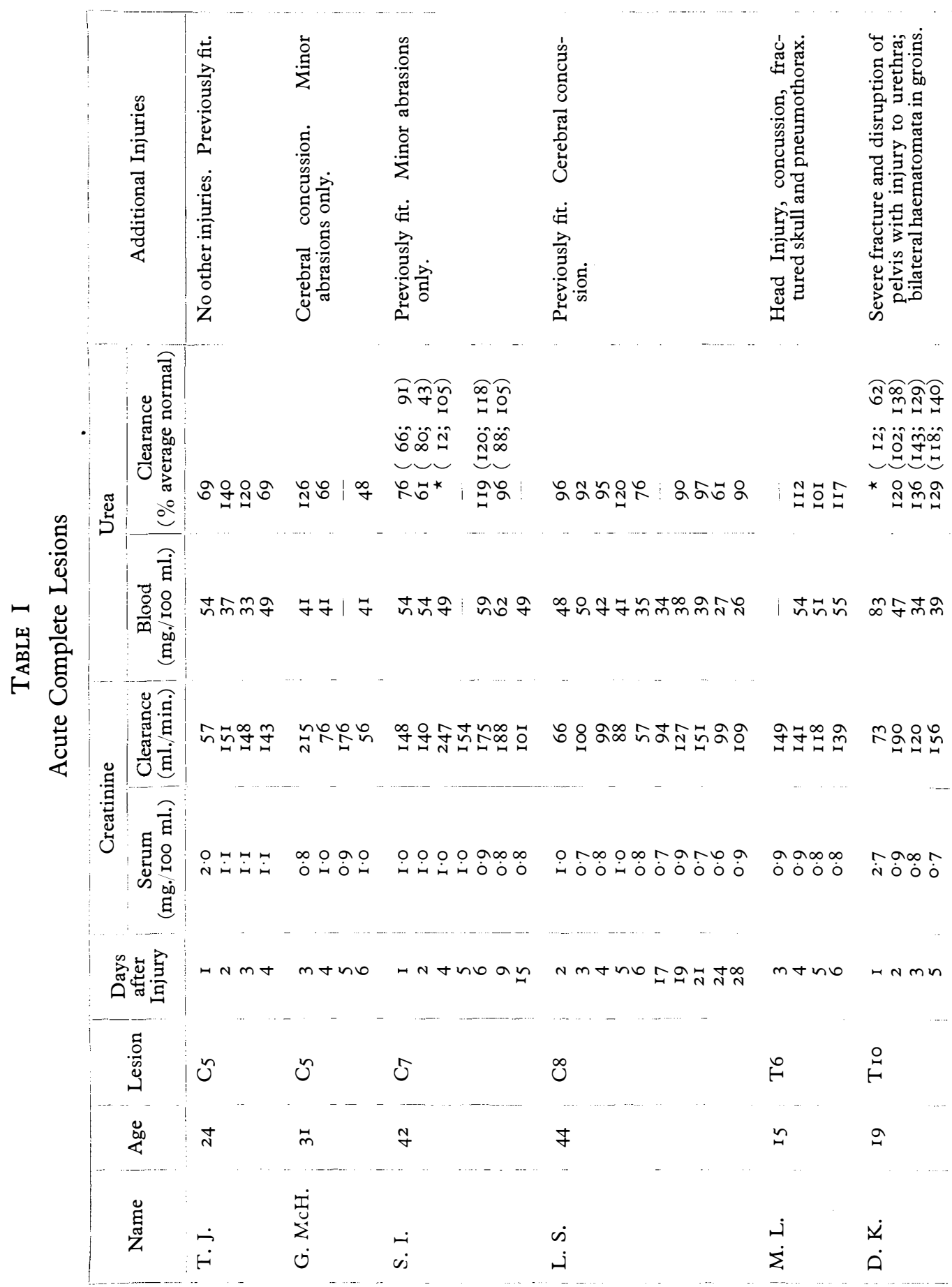



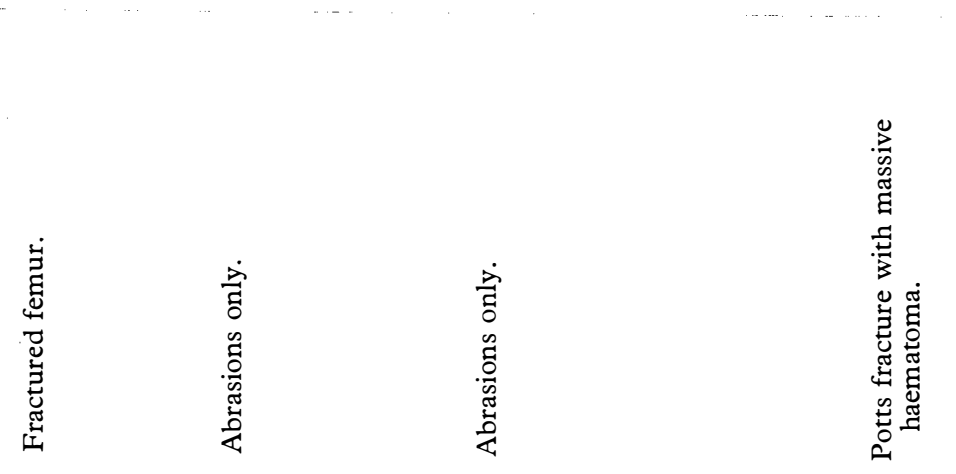

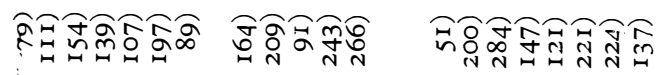

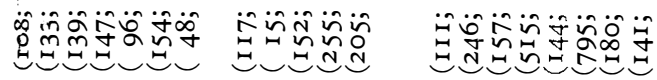

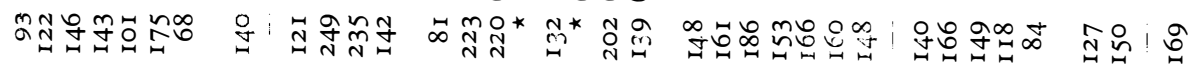

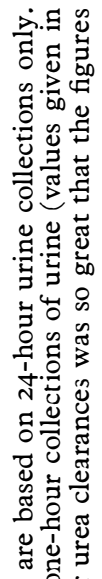

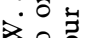

定峦

동

प्रें

垔

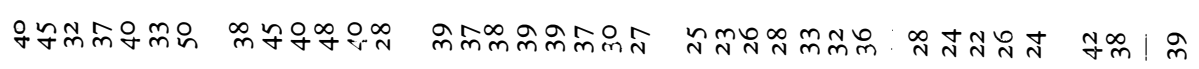

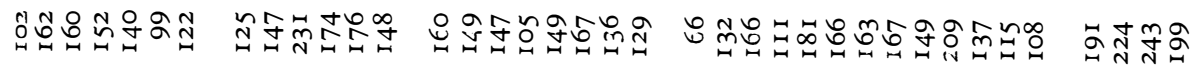

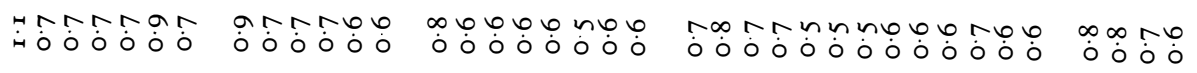

DOZmONM H

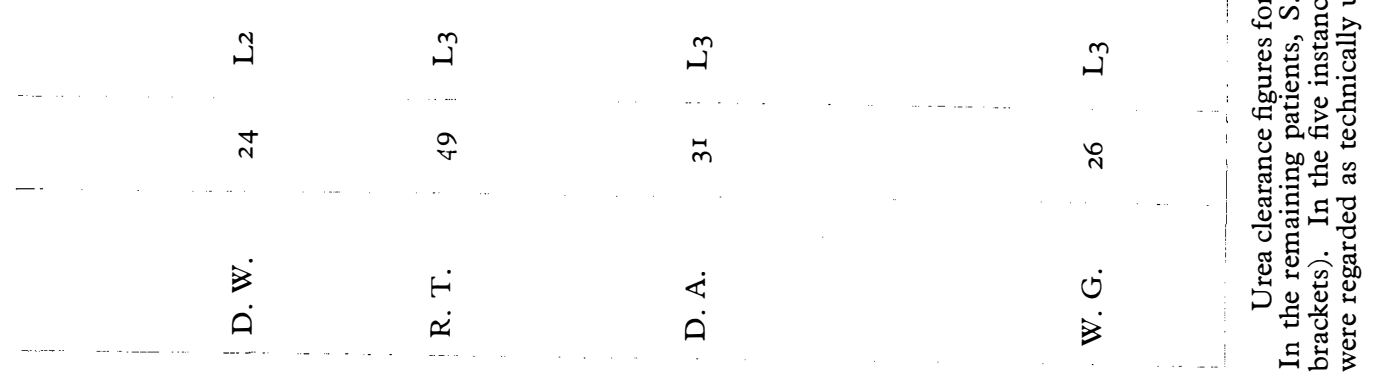

0.0

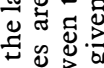

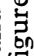

$\geqslant$

४ं

$\therefore:$ :

نं

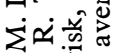

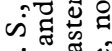

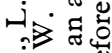

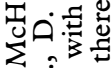

j.

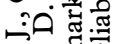

Hં 
urea levels had obvious major injuries from which the absorption of haematoma could be expected to cause a pre-renal azotaemia.

(b) Chronic Cases. Eighteen patients were suffering from chronic pyelonephritis. There were two groups: the first group concerned five patients who were injured at least ro years previously and Io patients who were diagnosed either by rectal biopsy or post-mortem as suffering from amyloidosis. The results obtained are shown in Table II.

Four of the five patients without signs of amyloidosis (C. H., G. B., C. L. and B. J.) had raised serum creatinine values and creatinine clearances below the normal range. There was a poor correlation between the blood urea levels and the urea clearance figures. In these cases and in the cases L. H. and C. L. the blood urea was found to be normal although the urea clearance was pathologically low. It is of interest that G. T. L., who had been injuried for 20 years, had normal blood and clearance values of both creatinine and urea in spite of long-standing infection leading to renal calculosis, hydronephrosis and bilateral reflux.

The ten cases suffering from amyloidosis can be divided into: $(a)$ those in terminal renal faulure (H. M., M. F., P. R., W. C. and G. A.) in whom, as one would expect the blood values are greatly raised and the clearance figures extremely low, and (b) the remaining five (G. W., K. W., G. M., P. O'D. and W. B.), all but one (P. O'D.) of whom had normal blood values and only slightly or moderately impaired clearance figures. Case P. O'D. appeared to be more severely affected, with raised blood values and very low clearance figures. Additional studies of tubular function were carried out on the four less severely affected cases (G. W., K. W., G. M. and W. B.) where in all cases an impaired concentrating ability was found as none could raise the osmolality of the urine above $577 \mathrm{mOsm} . / \mathrm{kg}$. (normal, $750 \mathrm{mOsm} . / \mathrm{kg} ., \mathrm{De}$ Wardener, I956).

The second group of chronic cases consists of three patients who showed signs of renal impairment within 14 months of injury. Table III gives the details and is arranged in a similar manner to Table I. The reasons why these patients developed such early renal impairment are of the greatest interest and importance.

D. B. had in addition to his spinal cord injury at T5, a large haemothorax; two days after injury his serum creatinine and blood urea were raised and creatinine clearance was below normal. The serum creatinine and blood urea had fallen by the I Ith day, but the creatinine clearance had not altered. He developed a persistent urinary infection after two months and a cystogram at six months showed reflux on the right. At that time his serum creatinine ( $\mathrm{I} \cdot \mathrm{I} \mathrm{mg}$./ $100 \mathrm{ml}$.) was in the upper range of normal, his creatinine clearance $(86 \mathrm{ml} . / \mathrm{min}$.) was low normal, the blood urea $(32 \mathrm{mg} . / 100 \mathrm{ml}$.) was normal, and the urea clearance (48 per cent. av. normal) was low. The infection proved resistant to all forms of treatment and he now uses an indwelling catheter. By seven and a half months the serum creatinine was normal but the clearance had fallen to its lowest value $(40 \mathrm{ml} . / \mathrm{min}$.) and although the blood urea was normal, the urea clearance was also low (57 per cent. av. normal). It would appear that the persistent infection is not limited to the lower urinary tract but has affected the functional integrity of the kidney.

T. H. is in contrast with the previous case in that, following his cord lesion at Ti2, his bladder was well rehabilitated and he was discharged from hospital eight months after injury with a blood urea of $4 \mathrm{I} \mathrm{mg}$./ $/ 100 \mathrm{ml}$. and with sterile urine, wearing a condom urinal. $\mathrm{He}$ was readmitted after a further five months with a residual urine of $20 \mathrm{oz}$. and little secretion on the I.V.P. His urine was infected and there was proteinuria. Since that time there has been a persistent impairment of renal function as shown by the raised 


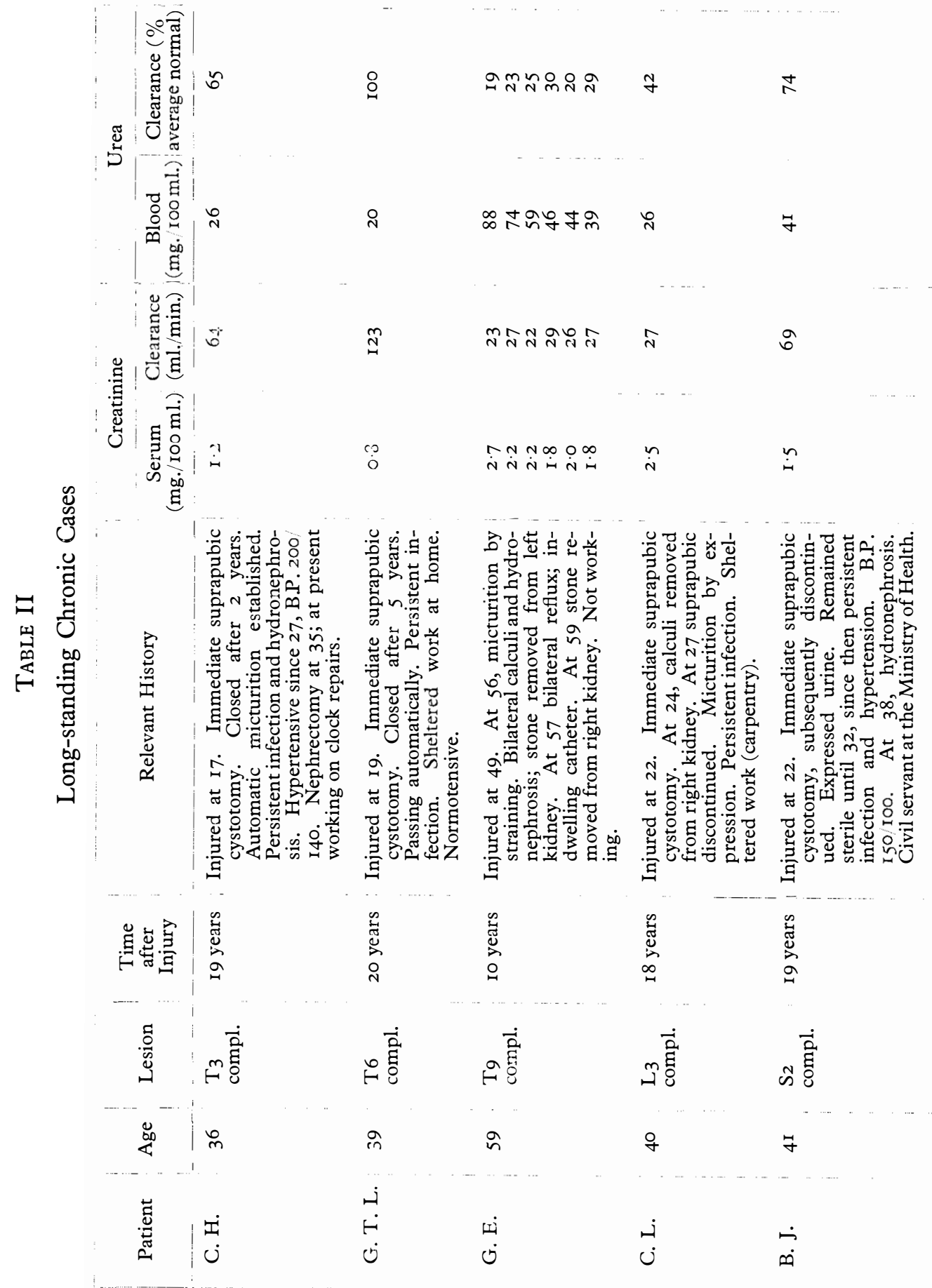




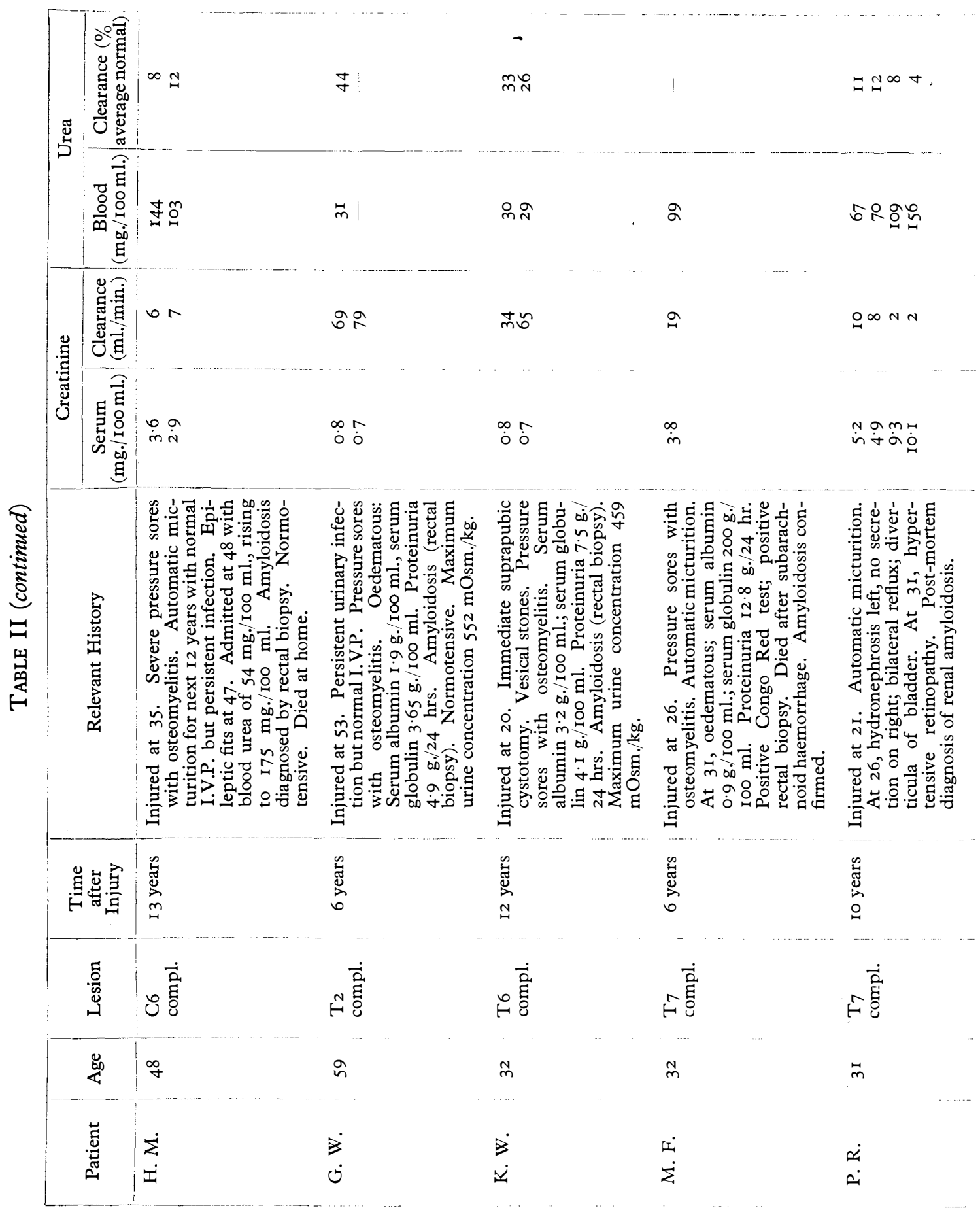




\begin{tabular}{|c|c|c|c|c|}
\hline $1: \stackrel{m}{m}$ & $\exists \stackrel{N}{ }$ & 1 & 음 & $\approx i$ \\
\hline 에 $\mathfrak{N}^{\infty}$ & 28 & 움 & \& & $\underset{\sim}{+\infty}$ \\
\hline ๖๘n & $\approx N$ & $m$ & $\Xi$ & $D N$ \\
\hline $\begin{array}{l}\hat{0} \boldsymbol{\infty} \hat{0} \\
\dot{0} \dot{0}\end{array}$ & $\stackrel{\infty}{\dot{i}} \dot{i}$ & $\stackrel{\infty}{\dot{b}}$ & $\overrightarrow{i n}$ & $\stackrel{0}{n}$ \\
\hline 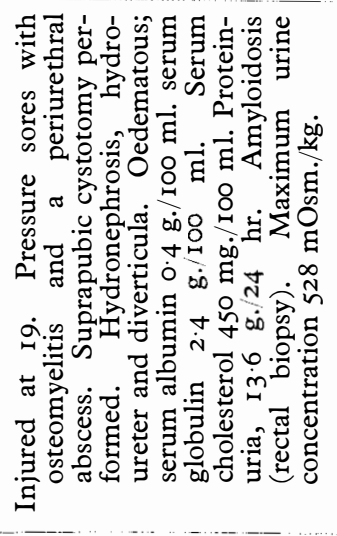 & 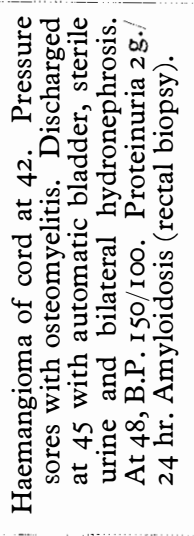 & 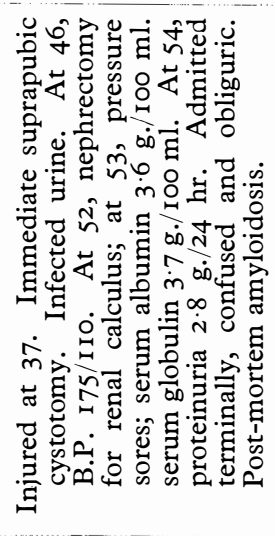 & 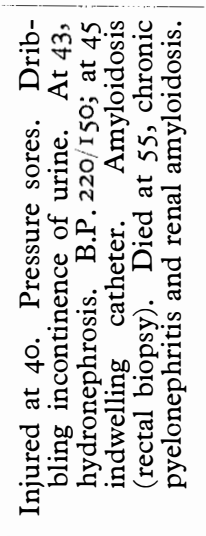 & 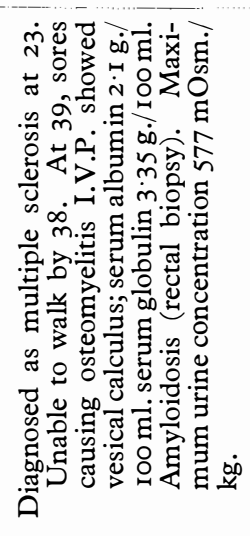 \\
\hline 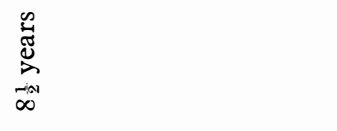 & 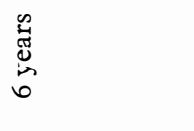 & 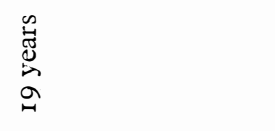 & 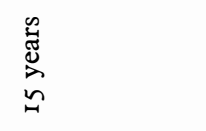 & 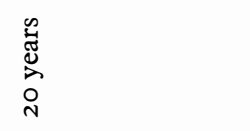 \\
\hline 䓌 & $\vec{G}$ & 염 & 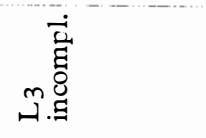 & 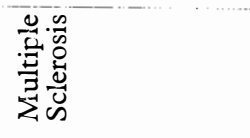 \\
\hline$\hat{N}$ & $\stackrel{\infty}{\forall}$ & o & $n$ & $m$ \\
\hline$\dot{\Sigma}$ & $\dot{0}$ & $\dot{u}$ & $\dot{4}$ & $\dot{\varphi}$ \\
\hline$\dot{0}$ & ai & $\dot{8}$ & $\dot{0}$ & $\dot{z}$ \\
\hline
\end{tabular}


serum creatinine and blood urea and the reduced creatinine clearance. A diagnosis of amyloidosis was made by rectal biopsy 19 months after injury.

I. M. showed a response similar to other cases in the first days after injury (cf. Table I); he had a normal serum creatinine level, all three creatinine clearances were normal, two blood urea levels were above normal and the urea clearance was normal. He developed a severe urinary infection at eight weeks; subsequently a dilated right ureter was found. At 19 weeks he had a severe exacerbation of his urinary infection, his blood urea rising to $204 \mathrm{mg}$./100 ml. The severe impairment of renal function is shown by the serum creatinine of $2.0 \mathrm{mg}$./100 ml., with a clearance of $4 \mathrm{I} \mathrm{ml}$. $/ \mathrm{min}$. His subsequent improvement under intensive therapy can be seen in the falling serum creatinine and blood urea levels and the rising creatinine clearance.

\section{DISCUSSION}

From all the data given in this paper it would appear that in the acute cases urea clearance is not a suitable test of renal function, as the rate of urine secretion is generally much less than $2 \mathrm{ml}$. $/ \mathrm{min}$. owing to fluid retention, especially in high lesions, and cannot be increased by increasing the water intake. When urine is secreted at these low rates the proportion of urine reabsorbed in the tubules is increased. Various formulae have been devised to allow for this, but they do not express the true clearance. In our cases when the urine flow was less than $2 \mathrm{ml}$./ min. we used the formula of Van Slyke ${ }_{B} \backslash V$. As can be seen from Table I when two one-hour collections were used there was generally a definite discrepancy between the clearances for the two consecutive hours. We had to use 24-hour collections in some urea clearance tests, as some of the patients were on intermittent catheterisation and were secreting low volumes of urine.

The endogenous creatinine clearance does not suffer from these disadvantages since the clearance does not vary with the urine flow. As the serum of creatinine remains stable for long periods (Tobias et al., I962) 24-hour level collections can be used minimising the inaccuracy of the clearance test arising from the technique of urine collections and from careless timing. The greater stability of creatinine in urine as compared with that of urea is an additional advantage.

Miller and Winkler (1938) introduced endogenous creatinine clearance tests and this has been widely used as a measure of glomerular filtration rate. While in healthy individuals the clearance gives values essentially the same as those determined by inulin clearance, it is controversial whether this is the case in disease. Tjan et al. (1963) used creatinine clearance tests to study the question of acute and chronic renal disease in non-paraplegic patients. Graber and Sevitt (I959) used the creatinine clearance as a measure of glomerular filtration rate in oliguric patients following severe burns and presented evidence to show that the ratio

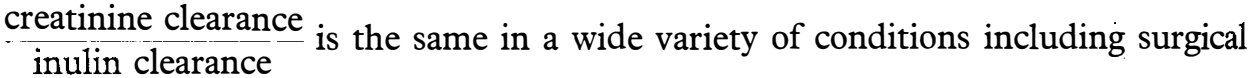
shock following trauma.

On the other hand Berlyne et al. (1964) found in five out of six cases with mild impairment of renal function (five nephrotic and one with hypertension) gross discrepancies between glomerular filtration rate measured by inulin clearance and that measured by creatinine clearance and came to the conclusion that endogeneous creatinine clearance was not a reliable measure of glomerular filtration rate in their cases. 


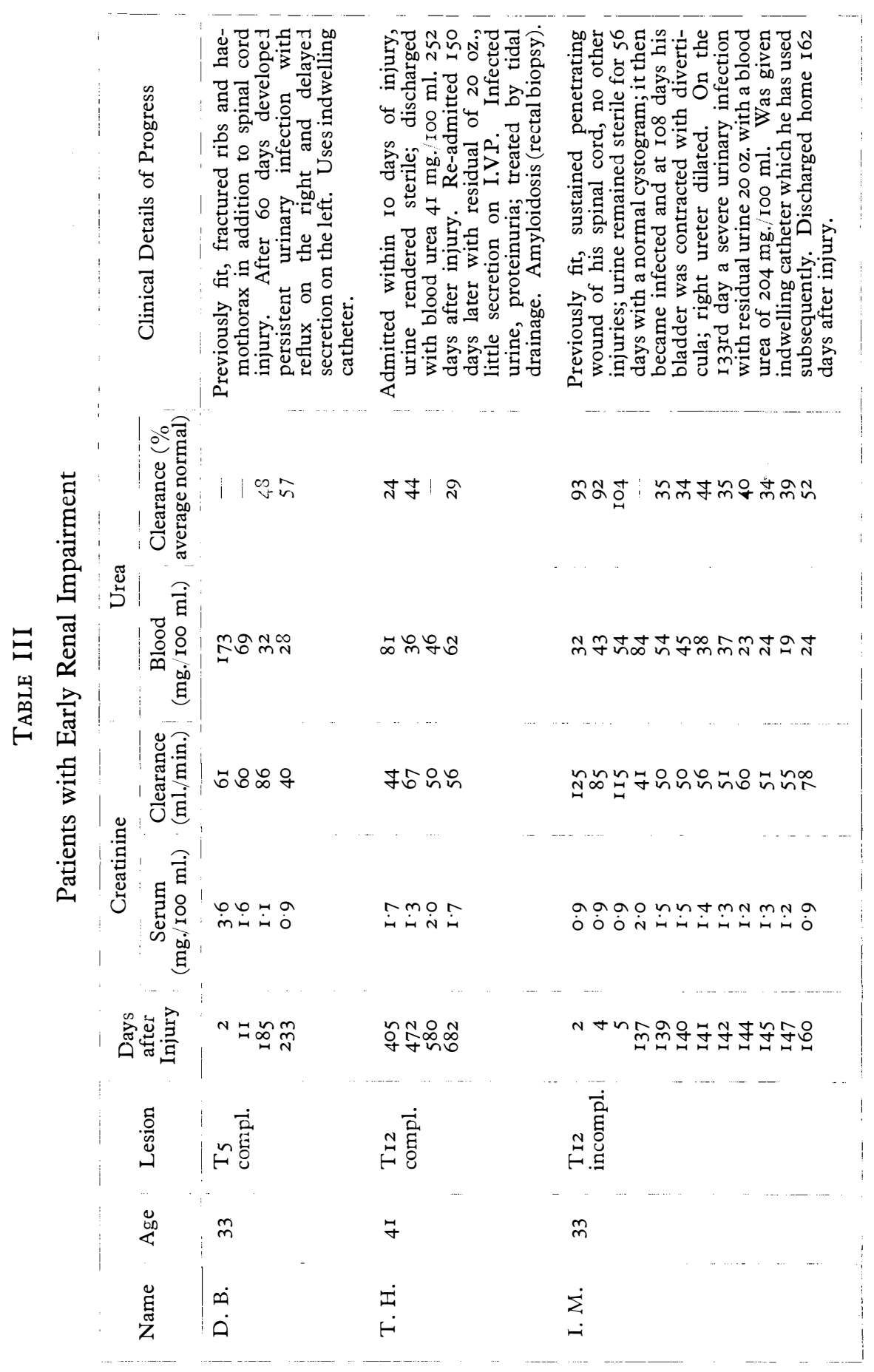


The major disadvantage of creatinine clearance tests lies in the difficulty of deciding what is actually measured in the serum. The use of Lloyd's reagent with a filtrate produced from a mixture of serum and protein precipitants in the recommended proportion 'provides at present the most satisfactory method in the determination of creatinine' in serum (Owen, et al., 1954). Bearing this in mind we found that the creatinine clearance test gave reproducible results.

In the group of acute cases we studied the effect of the level of the spinal cord transection on the renal function. In particular, we were interested whether or not the sudden interruption of the sympathetic control in complete lesions above $\mathrm{T}_{5}$ and in cervical lesions had any influence on renal function. No other work on this problem seems to have been published so far. Our findings clearly indicate that the level of the cord injury does not influence the creatinine clearance. The creatinine clearance as a reflection of glomerular filtration rate was found to be remarkably normal in the early stages following cord transection, thus indicating that the continuity of the spinal cord with the brain stem and the segmental innervation of the kidneys is not essential for the maintenance of a normal glomerular filtration rate. It is possible that the abnormal creatinine values on the first day after injury in $\mathrm{T}_{3}$ and $\mathrm{D}$. K. (Table I) are due to severe traumatic shock. In contrast, the blood urea level was profoundly raised in the early days following spinal injury as a reflection of tissue breakdown resulting from more or less large haematomata and other associated injuries of the spinal cord lesion.

In the chronic cases we were studying the effects of chronic urinary infection on renal function. Our findings of low creatinine clearance in these cases confirm the results of other workers in this field, suggesting as the main cause of damage chronic pyelonephritis (Rogers \& Bors, I950; Morales et al., I956; Magee, I957, 1958). Morales et al. and Magee in serial studies using the inulin clearances test as a measure of glomerular filtration rate found a progressive decrease in the clearance. Our findings in the chronic cases are in accordance with this work. The terminal cases of chronic renal infection all showed a low glomerular filtration rate, and there was a good agreement between creatinine clearance and urea clearance tests. In the other chronic cases including those in whom a diagnosis of amyloidosis was made by rectal biopsy, the various figures were not generally severely reduced, but the presence of tubular damage in four instances could be deduced from the marked impairment of concentrating ability. That renal damage may occur within as short a time as 14 months is well brought out by the three cases reported above (Table III).

Finally, attention is drawn to a major error which, in any clearance study in paraplegic and tetraplegic patients may be caused by the technique of urine collection. When urine secretion over a given period of time is not completely recovered from the bladder large errors may be introduced into the calculation. It is well known that in paraplegic patients who are not catheterised the residual urine may be as high as $300 \mathrm{ml}$. Even when a catheter is inserted it may be difficult to empty the bladder completely, in particular in flaccid lesions. Smith (I95I) suggested washing out the bladder with saline and subsequent expulsion of this by air in order to achieve complete emptying. It was found in this and other spinal centres for some time that in the recumbent paraplegic patient the lowest point of the bladder is not necessarily drained by the catheter and that further urine may be obtained by abdominal expression of the bladder or at sitting or standing such a patient up. Rosenheim (1963) has emphasised that when reflux is present further urine may be 
obtained after the act of micturition has been completed. Guttmann (I963) has pointed out that in paraplegics and tetraplegics in whom bladder infection can be avoided and the urine remains sterile, the incidence of reflux is either non-existent or very rare, but there is no doubt that the incidence of reflux amongst paraplegics with infected urinary tract is appreciable and can be a further source of error.

We have examined the problem of residual urine in 20 patients. In Io the bladders were drained and expressed when the patients were in the recumbent position, and as their clinical condition precluded their standing the head of the bed was elevated two feet and the procedure repeated. The greatest quantity of urine thus obtained was $16 \mathrm{ml}$. In Io chronic patients with indwelling Foley catheters, who were already able to stand in parallel bars or on crutches, the bladders were first drained while they were recumbent on a couch, and then aspirated by syringe. Finally the patients stood between parallel bars and the procedure was repeated. The volume of urine obtained varied from $0 \mathrm{ml}$. to $\mathrm{I} 4 \mathrm{ml}$. Therefore, while in patients who are catheterised the error in urine collection may be smaller, in the chronic patients who are expressing their bladder or passing automatically the presence of considerable residual urine would suggest that clearance studies in paraplegics may be useless unless a catheter is used.

\section{SUMMARY}

Comparative studies on the endogenous creatinine and urea clearances were undertaken in 28 paraplegic and tetraplegic patients. The patients were studied at various stages following spinal cord injury. Special attention was paid to the renal function in the immediate and very early stages after spinal cord transection.

The creatinine clearance test was found superior to the urea clearance test as a measure of glomerular filtration rate.

No significant influence of the level of the spinal cord transection on renal function was observed.

In the acute stages glomerular filtration rate as indicated by the creatinine clearances test was found remarkably normal. In contrast the blood urea level was profoundly raised as a reflection of the tissue breakdown.

Our findings of low creatinine clearance in the chronic cases were in accordance with the results of other workers in this field, indicating that the main cause of renal damage is chronic pyelonephritis.

\section{RÉSUMÉ}

Les études comparatives des clearances endogènes de la créatinine et de l'urée ont été entreprises chez 28 paraplégiques et tétraplégiques.

Ces malades ont été étudiés à différents moments après l'atteinte médullaire.

L'étude de la fonction rénale a été spécialement étudiée, immédiatement après et dans la phase aiguë, suivant l'atteinte médullaire.

Le test de clearance à la créatinine a été trouvé comme plus indicatif que celui de l'urée comme mesure du taux de filtration glomérulaire.

Aucune influence significative du niveau de l'atteinte médullaire par rapport à la fonction rénale n'a été observée. Au stade aigü, le taux de filtration glomérulaire indiqué par la clearance à la créatinine était remarquablement normal. Par contre, le taux d'urée sanquine était considérablement élevé, ceci réfléchissant les perturbations cataboliques tissulaires.

Nos résultats sur l'abaissement de la clearance à la créatinine, dans les cas chroniques, en comparaison avec les résultats des autres chercheurs dans ce domaine, indiquent que la pyélonéphrite est la principale cause de l'atteinte rénale. 


\section{ZUSAMMENFASSUNG}

Vergleichende endogene Kreatinin und Urea Ausscheidungsstudien wurden an 28 Paraplegikern und Tetraplegikern ausgeführt. Die Patienten wurden in verschiedenen Stadien nach der Rückenmarksverletzung untersucht. Besondere Aufmerksamkeit wurde der Nierenfunktion in den Frühstadien der Querschnittslähmung gewidmet.

Die Kreatinin-Ausscheidungsmethode war der Urea-Ausscheidungsmethode überlegen. den.

Ein Einfluss der Höhe der spinalen Läsion auf die Nierenfunktion wurde nicht gefun-

In den acuten Stadien war die glomuläre Filtrationsrate im allgemeinen normal. Dage. gen waren Ureawerte im Blut erheblich erhöht als Ausdruck von Gewebszerstörungen.

Unsere Befunde einer erniedrigten Kreatinin-ausscheidung in den chronischen Fällen stimmen mit denen anderer Autoren überein und bestätigen als Hauptursache der Nierenschädigung die chronische Pyelonephritis.

\section{REFERENCES}

Berlyne, S. M., Varley, H., Nilwarangkur, S. \& Hoerni, M. (I964). Lancet, 2, 874. Bonsnes, R. W. \& Taussky, H. H. (1945). Quoted by Varley, H. (1954) in Practical Clinical Biochemistry, p. I43. London: Heinemann.

Breithaupt, D. J., Jousse, A. T. \& Wynn-Jones, M. (196I). Canad. med. Ass. F., 85, 73.

Comarr, A. E., Kawaichi, G. K. \& Bors, E. (196I). Proceedings of the Ioth Annual Clinical Spinal Cord Injury Conference, p. I. Amer. Veterans Adm.

Comarr, A. E. (1954). F. Urol., 72, 596.

Cook, J. B. (1960). Proc. R. Soc. Med. 53, 263.

Damanski, M. \& GibBon, N. (1956). Brit. F. Urol. 28, 24.

De Wardener, H. E. (196I) The Kidney, Normal and Abnormal Structure and Function, and Ed. London: Churchill.

Dietrick, R. B. \& Russi, S. (1958). F. Amer. med. Ass. 166, 4 I.

Graber, I. G. \& Sevitt, S. (1959). F. clin. Path. 12, 25.

GutTmann, L. (1953). In History of the Second World War, U.K. Medical Series, Surgery, p. 422. Ed. Cope, Sir Zachary. London: H.M.S.O.

Guttmann, L. (1963). Paraplegia, I, I84.

GutTMANN L. (1964). Münch. med. Wschr.

KIng, E. J. \& WootTon, I. D. G. (1956). Micro-Analysis in Medical Biochemistry, 3rd Ed., T. \& A. Churchill.

Magee J. H. (1957). Proceedings of the 6th Annual Clinical Paraplegia Conference, p. 32. Amer. Veterans Adm.

Magee, J. H. (1958). Proceedings of the 7th Annual Clinical Paraplegia Conference, p. I29.

Melvin, K. E. W., Farelly, R. O. \& NorTh, J. D. K. (I963). Lancet, 2, 537.

Miller, B. F. \& WinkLeR, A. N. (1938). F. clin. Invest. I7, 3 I.

Morales, P. A., Sullivan, J. F. \& Hotchkiss R. S. (1956). f. Urol. 76, 7 I4.

NyQuist R. H. (1960). Proceedings of the 9th Annual Clinical Spinal Cord Injury Conference, p. I09. Amer. Veterans Adm.

Owen, J. A., Iggo, B., Scandrett, F. J. \& Stewart, C. P. (1954). Biochem. F. 58, 426.

Reingold, I M. (1953). Proceedings of the 2 nd Annual Clinical Paraplegia Conference, p. I. Amer. Veterans Adm.

Rogers, G. W. \& Bors, E. (1950). F. Urol. 63, IOO.

RosenHeim, M. L. (1963). Brit. med. F. I, I433.

Smith, H. W. (I95I). The Kidney, Structure and Function in Health and Disease, p. 42. London: Oxford University Press.

Tjan. H. L., Tobias, G. J., Levin, R. \& Hopper, J. (1963). Calif. Med. 98, I2 I.

Tobias, G. J., McLaughlin, R. F. \& Hopper, J. (I962). New Engl. F. Med. 266, 317.

Tribe, C. (1963). Int. F. Paraplegia, I, I9.

Wrong, O. M. (1962). In Renal Disease, p. 400. Ed. Black, D. A. K. Oxford: Blackwell 